\title{
Depositional environments and landscapes of the upper Miocene Ipururo Formation at Shumanza, Subandean Zone, northern Peru
}

Augustin Feussom Tcheumeleu ${ }^{\mathrm{a}, \mathrm{b}}$, Séverine Fauquette ${ }^{\mathrm{a}}$, Angélica Aliaga Castillo ${ }^{\mathrm{c}, \mathrm{d}}$, Camila Martinez $^{\mathrm{c}, \mathrm{e}}$, Federico Moreno $^{\mathrm{c}, \mathrm{f}}$, Rosa E. Navarrete ${ }^{\mathrm{g}}$, Francisco Parra ${ }^{\mathrm{g}, \mathrm{h}}$, Frank P. Wesselingh ${ }^{\mathrm{i}}$, Rodolfo Salas-Gismondi $^{\mathrm{d}}$, Rafael Varas-Malca ${ }^{\mathrm{d}}$, Martin Roddaz ${ }^{\mathrm{g}, \mathrm{j}}$, Pierre-Olivier Antoine ${ }^{\mathrm{a}^{*}}$

${ }^{\text {a } I n s t i t u t ~ d e s ~ S c i e n c e s ~ d e ~ l ' E v o l u t i o n ~ d e ~ M o n t p e l l i e r ~(I S E M), ~ C N R S, ~ U n i v . ~ M o n t p e l l i e r, ~ I R D, ~ M o n t p e l l i e r, ~}$ France

${ }^{\mathrm{b}}$ Laboratoire de Paléoécologie, Département de Géographie, Université de Montréal, Chemin-de-la-Côte-SteCatherine, Montréal QC H2V 2B8, Canada

c Smithsonian Tropical Research Institute, Unit 0948, APO AA 34002, Balboa, Ancon, 0843-03092, Panama

${ }^{d}$ Departamento de Paleontología de Vertebrados, Museo de Historia Natural - Universidad Nacional Mayor de San Marcos, Lima, Peru

${ }^{e}$ L.H. Bailey Hortorium, Plant Biology Section, School of Integrative Plant Sciences, Cornell University, Ithaca, New York 14853, USA

${ }_{\mathrm{f}}^{\mathrm{f}}$ Earth \& Environmental Sciences, University of Rochester, 227 Hutchison Hall, University of Rochester, Rochester, NY, 14627, USA.

g Paleosedes E.U. Tv 27 n57-49 Campin, Bogotá, Colombia

${ }^{\text {h }}$ Géosciences-Environnement Toulouse, Univ. Toulouse, UPS (SVT-OMP), CNRS, IRD, Toulouse, France

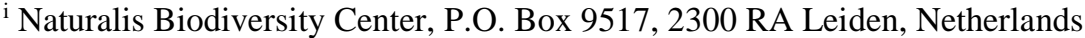

${ }^{1}$ Laboratório de Geocronologia, Instituto de Geociências, Universidade de Brasília, Brasília, DF 70910-000, Brazil

* corresponding author

\begin{abstract}
During the late Miocene, the Andean-Amazonian region experienced drastic climatic and environmental changes, notably due to a major phase in the Andean uplift. The fossil record is virtually undocumented for this period in the Subandean Zone, where very few palaeoenvironmental and palaeontological investigations have been undertaken. Here, we describe plant remains (pollen, spores, and leaves), microfossils, mollusks, and vertebrates from the Ipururo Formation at Shumanza, San Martín, Peru. Twenty-nine

plant families are identified from 164 pollen grains and 89 spores, among them Lycophytes, Monilophytes, and angiosperms (5 monocots and 18 eudicots). The pollen sample notably includes Grimsdalea magnaclavata, Palaeosantalaceaepites cingulatus, Echitricolporites spinosus, and Fenestrites longispinosus, pointing to a late Miocene-early Pliocene age for the TAR-27 locality (10.06-3.72 Ma). Leaf impressions, from nearby localities in the same section, document Malvaciphyllum sp. (Malvaceae), three morphs resembling Caryocaraceae, Fabaceae, Myrtaceae, and two unidentified 'Dicotyledonae' angiosperms. The mollusk assemblage is somewhat reminiscent of early-middle Miocene Pebasian faunas and dominated by gastropods (ampullariids, cochliopid, cerithioid, and planorbids). It also includes sphaeriid and unionoid bivalves. Vertebrate recovery is very poor, with a serrasalmine characiform and unidentified actinopterygian teeth. Fossil assemblages and sedimentary facies consistently testify to the dominance of riverine/alluvial forests and the persistence of a steady lowland rainforest close to the Andes less than 10.1 million years ago, without indication of (1) mangrove/marine environments or (2) high-elevation ranges in the close surroundings of Shumanza by that time. By coupling palynostratigraphy and lithostratigraphy, Shumanza fossil assemblages would be further assigned an early late Miocene age (10.1-ca. $8 \mathrm{Ma}$ ).
\end{abstract}

Keywords: Pebas mega-wetland system, Proto-Amazonia .Neotropical rainforest, Palynomorphs, Leaf impressions, Mollusks. 


\section{Introduction}

The Neogene environmental dynamics in westernmost Amazonia, at the foothills of the Andes, has received much attention in the last decades, launching fierce debates between geologists, palaeontologists, and palynologists (e.g. Hoorn 1993, 1994a; Räsänen et al. 1995; Campbell et al. 2001; Hoorn et al. 2010; Roddaz et al. 2010; da Silva-Caminha et al. 2010; Latrubesse et al. 2010; Boonstra et al. 2015; Antoine et al. 2016; Jaramillo et al. 2017). There is some consensus that the Andean-Amazonian region experienced drastic climatic and environmental changes during the late Miocene (11.8-5.3 Ma), with a major phase in the Andean uplift (Graham 2009; Hoorn et al. 2010; Mora et al. 2010; Roddaz et al. 2010; Armijo et al. 2015; Eude et al. 2015; Kar et al. 2016; Horton 2018) and the onset of the eastward transcontinental drainage of the Amazon River (Figueiredo et al. 2009; Hoorn et al. 2010, 2017; Gorini et al. 2014; Soelen et al. 2017).

From a palaeontological perspective, the late Miocene interval is well documented in the (low latitude) Western Amazonian lowlands (Brazil, Colombia, Peru, and Bolivia; Hoorn et al. 2010; Lundberg et al. 2010; Negri et al. 2010; Riff et al. 2010; Wesselingh and Ramos 2010; Ribeiro et al. 2013; Salas-Gismondi et al. 2015; Antoine et al. 2016; Jaramillo et al. 2017) and by places in the Andean Altiplano (Bolivia, Peru, and Colombia; e.g. Bershaw et al. 2010; Hulka and Heubeck 2010; Kar et al. 2016). Nevertheless, very few palaeoenvironmental and palaeontological investigations have been undertaken in the Subandean Zone, where the fossil record is virtually undocumented for this period. The Shumanza Section (San Martín Department, Huallaga Basin) is situated in the Subandean Zone of Northern Peru (Fig. 1). This section was investigated from a tectonosedimentary perspective in the past decades $(\log 6$, Juanjui-Tocache road; Hermoza et al. 2005). However, palaeontological studies have not been conducted prior to this work. Hermoza et al. (2005) reported a well-exposed succession of blackish marls interbedded in laminated limestones pertaining to the late Neogene Ipururo Formation (Fig. 2). Given the palaeontological potential of the concerned series, our multidisciplinary team undertook two field trips to Shumanza in 2014 and 2015, in order to recover micro- and macrofossil materials. This study aims at describing plant remains (pollen, spores, and leaves) from the Shumanza section, as well as associated microfossils, mollusks, and vertebrates, which allows in turn for refining the age of the section and providing a synthetic local palaeoenvironmental reconstruction for the concerned period.

\section{Stratigraphical and sedimentological setting}

In the Shumanza section (Fig. 2), the top of the Lower Member, the entire Middle Member, and the base of the Upper Member of the Ipururo Formation are well exposed in both flanks of a $\mathrm{N} 170^{\circ} \mathrm{E}$ syncline (Shumanza syncline), with beds dipping between $60^{\circ}$ and $70^{\circ}$ (Fig. 1). The 25-m-thick Middle Member mostly consists of massive black marls with lignite and mica debris, alternating with grey laminated calcarenites and fine-grained cross-stratified yellowish calcarenites, interpreted as hummocky cross stratifications (Hermoza et al. 2005). This Middle Member was formerly considered to represent westward transgressive storm deposits and it is unconformably overlaid by conglomerates and sandstones of the 35-m-thick Upper Ipururo Member, interpreted as documenting fluvial channel infill deposits (Fig. 2a; Hermoza et al. 2005).

Fossils were found on both flanks of the syncline, in black marls (TAR-27 locality, east to the axis of the syncline) and laminated calcarenites (TAR-27, TAR-51, and TAR-52 localities, west to the core; Fig. 1 and Table 1). These three localities are interpreted as documenting successive horizons within the Middle Member of the Ipururo Formation, with the upward sequence TAR-52-TAR-51-TAR-27 (Fig. 2a).

In the Shumanza section, the fossil-yielding interval is unconformably overlain by a boulderrich conglomeratic unit, assigned to the Upper Member of the Ipururo Fm. (Hermoza et al. 
2005: figure 10). This sequence is suggestive of a brutal shift in local hydrodynamics, probably related to the upper Miocene formation of the Huallaga Subandean Zone (Eude et al. 2015).

\section{Materials and methods}

\section{Material}

Palynomorphs, microfossils (charophyte oogonia and ostracod fragments), mollusks, and vertebrates originate from the greyish to blackish mica- and lignite-rich marl levels of the Middle Ipururo Member (TAR-27 locality; S 7³2'7.45" W 76²0'32.24"; Fig. 2b, c) and have been extracted independently. Leaf imprints were recovered in the laminated calcarenites from the same interval at TAR-27, TAR-51 (S 7³2'3.34" W 76² 41'4.74"; Fig. 2d), and TAR-52 (S $7^{\circ} 31^{\prime} 58.98^{\prime \prime}$ W 76 41'9.96"; Fig. 2e). Sediments of the TAR-52 locality and other levels were barren of both pollen and spores or any other palynomorphs.

The locality TAR-51 is registered with the number 110057 at the Smithsonian Tropical Research Institute database. In this locality, abundant leaf material was collected; the succession was dominated by mudstone, sandstone, and muddy sandstone beds. The fossils were specifically collected from grey mudstone beds interbedded with yellowish oxidized mudstones with slight lamination, and also from a yellow, massive, coarse-grained sandstone bed.

\section{Methods}

\section{Palynomorph extraction and preparation for light microscope}

Five cubic centimeters of the TAR-27 material was crushed and treated with $20 \%$ hydrochloric acid $(\mathrm{HCl})$ to dissolve the carbonates. The residue was treated with $10 \%$ sodium hexametaphosphate ((NaPO3)6) to remove clay and afterwards with 50\% nitric acid (HNO3) to dissolve and remove the organic matter. We applied high-density zinc chloride $(\mathrm{ZnCl} 2)$ leading pollen grains and spores in the supernatant which was then poured into a clean tube, washed with $20 \% \mathrm{HCl}$, and then sieved (10 $\mu \mathrm{m}$ meshes) to remove the clay fraction. This residue was washed with ethanol $(\mathrm{C} 2 \mathrm{H} 6 \mathrm{O})$ and finally, few drops of glycerinwere added.A part of the organic residue was mounted on five $22 \times 32 \mathrm{~mm}$ slides, then sealed with histolaque. The slides are not fixed and have limited lifetime. However, the rest of the sediments and residue used are preserved at ISEM (Institut des Sciences de l'Evolution, Montpellier).

In total, 253 palynomorphs were counted under a Leica DMLB binocular microscope with $\times 63$ objective. For the identification, we used the publications of Hooghiemstra (1984), Roubik and Moreno (1991) Hoorn (1994a), Herrera and Urrego (1996), Colinvaux et al. (1999), Punt et al. (2007), Leite (2009), da Silva-Caminha et al. (2010), Teunissen van Manen (2015a, 2015b), Jaramillo and Rueda (2016), and the reference collection of the Institut des Sciences de l'Evolution de Montpellier (ISEM).

\section{Fossil leaf curation, preparation, and documentation}

The fossil leaves of this locality are impressions of angiosperms, which were studied and stored at the Paleontological Collection of the Museo de Historia Natural de la Universidad Nacional Mayor de San Marcos Lima, Peru (DPV-MHNUNMSM). The removal of sediment from surface of plants was done using air compressor flow to expose the maximum number of leaf characters. The materials were examined with a LEICA EZ4 HD coupled to an integrated 5.0 megapixel CMOS camera.

Fossil leaves were organised and described by morphotypes following the method proposed by Peppe et al. (2008). Each morphotype has a two-letter prefix (IP) based on the formation name plus a number starting from one. Comparisons with extant material were done with the collection of the San Marcos Herbarium (USM), MHN-UNMSM, Lima, Peru and virtual 
collections, accessed through the JSTOR Global Plants database (Appendix 1). Herbarium specimens from USM were photographed with a Samsung NX30 camera. All descriptions were done following the terminology of Ellis et al. (2009).

Taxonomic affinities of the leaf morphotypes were proposed when possible based on the presence of taxonomically informative characters (shape, size, margin type for instance), extant material available for comparison, and completeness of the description of each morphotype. Moreover, venation was preserved in some specimens, which is a good character to differentiate dicotyledonae leaves from monocot ones but also to make distinctions within each of these groups.

\section{Microfossils and microfacies}

Another part of the sediment samples was processed using standard micropalaeontological methods. The samples were heated to $40{ }^{\circ} \mathrm{C}$ during $30 \mathrm{~min}$, added $300 \mathrm{ml}$ of stock solution without enzymatic detergent, and boiled gently for $2-3 \mathrm{~h}$ until a sufficient material had disintegrated. After a first wash, the residues were placed in a hydrogen peroxide 40 vol solution for 18-24 h until the material was disintegrated. After disaggregation, samples were washed with sodium hexametaphosphate $(10 \%)$ over $250-\mu \mathrm{m}$-mesh sieves to remove clay and silt. For each sample, a micro-splitter was used to obtain a known fraction which was spread over a standard picking tray. The picking was realised under a Wild stereomicroscope $(\times 800)$. If no specimens were observed after three tries, the sample was qualified as barren. Picking was focused on microforaminifers and ostracods, and other aleatory microfossils. The picked specimens were examined using an Olympus stereomicroscope (Stereozoom $\times 1000$ ). Unfortunately, the samples analysed were barren in microfossils in situ. The micro-remains of other organic particles were placed in class categories and microfacies were defined.

\section{Mollusks and vertebrates}

Black clays were scrutinized thoroughly in the field and fossil rich samples were collected then stored in aluminum foil to slow down dehydration and subsequent breakage. Large mollusk specimens uncovered were prepared mechanically at the laboratory with a mounted pin, then fixed with cyanoacrylate glue. Vertebrate specimens and small mollusks were concentrated by screen-washing $\sim 10 \mathrm{~kg}$ of sediment $(1 \mathrm{~mm}$ mesh), using diluted hydrogen peroxide. Noticeably, by this procedure, a fragmentary carbonized fruit shell and a couple of charophyte oogonia showing no sign of erosion/redeposition were also obtained (Fig. 6h, i).

\section{Methods for palaeoenvironmental reconstruction}

We have chosen to identify the fossil pollen and spores following current taxonomy of recent taxa, as for Quaternary studies (Suc et al. 2004), instead of using morphotaxa names (e.g. Hoorn 1993, 1994b, 2006; Leite 2009; da Silva-Caminha et al. 2010; Goillot 2010; Jaramillo et al. 2010; Latrubesse et al. 2010). By applying such approach, we assigned our palynomorphs to family, genus, and sometimes even to species levels. Once palynomorphs were botanically identified, we determined their palaeoecological requirements based on the modern taxa following Hoorn (1993, 1994b), Marchant et al. (2002), Leite (2009), Jaramillo et al. (2010), Barreto et al. (2015), and D'Apolito (2016) (Table 2). This botanical approach thus allows reliable palaeoecological interpretation. The joint study of the sedimentary facies, vegetation, mollusk, algae, charophyte, and vertebrate assemblages documented at TAR-27 led to palaeoenvironment reconstruction at Shumanza that was then compared with palaeoenvironmental and palaeogeographic reconstructions available for Western Amazonia (e.g. Hoorn 1994a; Hermoza et al. 2005; Hoorn et al. 2010; Roddaz et al. 2010; Salas-Gismondi et al. 2015; Antoine et al. 2016, 2017). 


\section{Results}

Pollen and spores

In total, we counted 164 pollen grains and 89 spores, and we identified 29 plant families on the five prepared slides. Among the identified families, 6 are Lycophytes and Monilophytes and 23 Angiosperms including 5 monocots and 18 eudicots (Table 2, classification based on Cole et al. 2018, 2019). Twenty-three pollen grains and 60 spores remain uncertain. We were able to identify 29 taxa up to the family level, but only 22 at genus level, and only 5 at species level and the main taxa are illustrated (Figs. 3 and 4). Figure 4 illustrates complementary data originating from a preliminary test sample at TAR-27.

Angiosperms ( 39\%) most frequent in the main sample are Combretaceae/Melastomataceae (Eudicots; 14.6\%), Tetrapterys (Eudicots, Malpighiaceae; 10.2\%), Stigmaphyllon (Eudicots, Malpighiaceae; 4.7\%), Cyperaceae (Monocots, Poales; 3.5\%), Mauritia (Monocots, Arecaceae; 3.1\%), and Asteraceae (Eudicots; 2.7\%). Many Monilophytes such as Ceratopteris sp. (Parkeriaceae), Pityrogramma sp. (Pteridaceae), and Cyathea sp. (Cyatheaceae) are recognized (Table 2, Fig. 3).

Other key taxa have been identified punctually such as Grimsdalea magnaclavata (extinct Arecaceae), Cingulatisporites sp. (extinct Selaginellaceae), Palaeosantalaceaepites cingulatus (extinct Euphorbiaceae), and Asteraceae that may be related to Echitricolporites spinosus and to Fenestrites longispinosus (Figs. 3 and 4).

Microfossils and microfacies

The samples from TAR-27 are dominated by translucent phytoclasts and amorphous organic matter of algal origin (> 50\%). In several cases, the original structure of such algae is preserved, which allows for assigning them to Chlorococcales, and more precisely to the colonial planktonic microalga Botryococcus (Botryococceae; Fig. 4a). Representatives of Botryococcus are excellent environmental markers, and their predominance at TAR-27 indicates the obligate presence of a low salinity/freshwater steady body of water (Guy-Ohlson 1992; Batten and Grenfell 1996; Medeanic 2006). This TAR-27 sample lacked calcareous and/or arenaceous microfossils, but contains small snail shells and fragmentary crab molts. Rare fragments of charophyte oogonia were also observed.

\section{Leaf impressions}

Thirty-two leaf fragments were recovered from TAR-51 (STRI 110057 locality) (Figs. 5 and 6). However, only 11 of them were well enough preserved to be described and grouped into morphotypes. Six leaf dicotyledonae angiosperm morphotypes were recognised. The term 'dicotyledonae' is used as the leaves could be included in Magnoliids or in Eudicots following the up-to-date flowering plant systematics by Cole et al. (2019). The laminar size was mostly microphyll. The leaf margin was variable, three leaf morphotypes have entire margins, while the other three morphotypes have toothed margins. Only one morphotype was formally identified to a fossil morphogenus. Three morphotypes were assigned by best guess to family level (IP1, IP2, and IP4), and two morphotypes could not be identified (IP3 and IP5) (Fig. 5).

\section{Systematics}

Family Malvaceae Jussieu, 1789

Subfamily Malvoideae

Genus Malvaciphyllum Anzótegui and Cristalli, 2000

Species Malvaciphyllum sp. 
Studied material: DPV-MHN-UNMSM-STRI-41430; 43993; 43994 (Fig. 5a).

Description: The microphyll leaf impressions bear an ovate shape and a length of $3.5 \mathrm{~cm}(2.6-$ $4.4 \mathrm{~cm})$ and a width of $1.73 \mathrm{~cm}(1.5-1.9) \mathrm{cm}$; the lamina has medial and basal symmetry. The apex has a straight shape and an acute angle (Fig. 5a1-2). The base has a cordate shape and a reflex angle (Fig. 5a1-4). The primary vein framework is actinodromous, with 5-7 veins arising from the base (Fig. 5a1-4). Major secondary veins are semicraspedodromous, excurrent, with a spacing gradually increasing towards the proximal side of the leaf; the angle of attachment to midvein is smoothly decreasing proximally. Agrophic veins are compound. Minor secondaries are craspedodromous. Intersecondaries are less than half the length of subjacent secondaries and have a proximal course that is parallel to major secondaries and a reticulated distal course. Tertiary venation is alternate percurrent. Areolation is moderately developed (Fig. 5a1, 2 and 4). The teeth are irregularly spaced with five teeth/cm and they occur in two orders of teeth distinguished by their size. The first and second order teeth are convex-convex in shape, and their sinuses are angular. Teeth exhibit a medial principal vein that terminates at the tooth apex (Fig. 5a4-6).

Source, age and stratum: Peru, Huallaga Basin, Middle Ipururo Formation. San Martín Department, Juanjui to Tocache road, $7^{\circ} 32^{\prime} 3.34^{\prime \prime S} 76^{\circ} 41^{\prime} 4.74 " \mathrm{~W}$, at $375 \mathrm{~m}$, locality 110057 (TAR-51). Late Miocene.

Remarks: The combination of characters present in this morphotype is consistent with and indicative of Malvaceae. These shared characters are the presence of leaves with actinodromous venation, and distinctive teeth venation, in which the principal and accessory veins are terminating at the tooth margin without any type of glandular thickenings or processes. This morphotype exhibits the same character combination that is distinctive to the clade Malvoideae of Eumalvoideae based on the definition of Carvalho et al. (2011). The presence of actinodromous primary venation with more than five basal veins, compound agrophic veins, craspedodromous minor secondary veins, alternate percurrent third order veins, branched freely ending veinlets and dentate margin with a reflex angle teeth base support this designation.

\section{IP1 (Fig. 5b)}

Systematic affinity. Dicotyledonae Angiosperm; Order, Family, and Genus incertae sedis.

\section{Morphotype specimen. DPV-MHN-UNMSM-STRI-413995 (Fig. 5b).}

Description. These notophyll leaf impressions show an oblong shape, a medial and basal asymmetry and a length of $7.2 \mathrm{~cm}$ and a width of $2.5 \mathrm{~cm}$. The base has a straight shape and an acute angle (Fig. 5b1 and 3). The primary vein framework is pinnate, with one vein arising from the base. Major secondary veins are semicraspedodromous, excurrent, and have spacing decreasing towards the proximal side of the leaf; the angle of attachment to midvein is smoothly decreasing proximally. Intercostal tertiary venation is opposite percurrent and has a straight course, the angle of attachment to midvein is obtuse and increases proximally. Epimedial tertiaries are opposite percurrent and have a parallel course to the intercostal tertiaries. The teeth are regularly spaced with 4 teeth/cm and occur in one order of teeth. The teeth are convexretroflexed in shape, their sinuses are rounded and exhibit a cassidate tooth apex (Fig. 5b2).

Remarks. The combination of characters seen in IP1 (oblong and asymmetric laminar shape, semicraspedodromous major secondary veins, straight-opposite percurrent tertiary venation, with an obtuse angle of attachment to the midvein increasing proximally and one order of teeth with a cassidate tooth apex) resembles leaflets of Caryocaraceae. 
Systematic affinity. Dicotyledonae Angiosperm; Order, Family, and Genus incertae sedis.

Morphotype specimen. DPV-MHN-UNMSM-STRI-43996; 413997; 43998 (Fig. 5c).

Description. These microphyll leaf impressions show an entire margin and an oblong laminar shape with a length of $2.3(2.0-2.6) \mathrm{cm}$ and a width of $1.2(1.1-1.3) \mathrm{cm}$. The lamina has medial and basal symmetry. The apex has an emarginated shape and an obtuse angle (Fig. 5c5). The base has a rounded shape and an obtuse angle (Fig. 5c1-2). The primary vein framework is pinnate, with one vein arising from the base. Major secondary veins are craspedodromous, excurrent with a regular spacing; the angle of attachment to midvein is uniform. Perimarginal vein present. Intersecondaries are less than half of subjacent secondaries and have a proximal course parallel to major secondaries and a reticulated distal course. Epimedial tertiaries are ramified and have a proximal course parallel to the subjacent secondary veins. Areolation is poorly developed (Fig. 5c).

Remarks. The combination of characters seen in IP2 (oblong laminar shape, entire margin, symmetrical apex and base with a rounded and an obtuse angle, craspedodromous major secondary veins, marginal veins, ramified intersecondary veins, seldom reaching margin, ramified and poorly organized tertiary veins) is shared with the genus Machaerium (Fabaceae).

\section{IP3 (Fig. 5d)}

Systematic affinity. Dicotyledonae Angiosperm; Order, Family, and Genus incertae sedis.

Morphotype specimen. DPV-MHN-UNMSM-STRI-43999; 44000 (Fig. 5d).

Description. These microphyll leaf impressions have entire margins, an elliptic to obovate shape, a length of $4.14(3.82-4.46) \mathrm{cm}$ and a width of $2.6(2.12-3.07) \mathrm{cm}$. The lamina has medial and basal asymmetry. The apex has a convex shape and an acute-obtuse angle. The base has a convex shape and an acute angle (Fig. 5d). The primary vein framework is pinnate, with three veins arising from the base. Major secondary veins are eucamptodromous, decurrent with a spacing gradually decreasing towards the proximal side of the leaf, the angle of attachment to midvein is smoothly increasing proximally. Tertiary venation is irregular reticulate. Intersecondaries are less than half of subjacent secondaries and have a proximal course perpendicular to midvein and a reticulated distal course. Tertiary venation is irregular reticulate. Areolation is well developed.

Remarks. Due to the lack of preservation of the minor venation of this morphotype and the overlap of extant plant groups with similar leaf architecture, no possible taxonomic affinities for IP3 were proposed.

\section{IP4 (Fig. 5e)}

Systematic affinity. Dicotyledonae Angiosperm; Order, Family, and Genus incertae sedis.

\section{Morphotype specimen. DPV-MHN-UNMSM-STRI-44001 (Fig. 5e1-2).}

Description. These microphyll leaf impressions show an entire margin, an obovate shape, a length of $2.46 \mathrm{~cm}$ and a width of $0.62 \mathrm{~cm}$. The lamina has medial and basal symmetry. The apex has a convex shape and an acute angle and the base has a straight shape and an acute angle. The primary vein framework is pinnate, with 3 veins arising from the base. Major secondary 
veins terminate at the intramarginal secondary vein. They are excurrent with a spacing abruptly increasing towards the proximal side of the leaf, the angle of attachment to midvein is smoothly decreasing proximally. Marginal secondary vein is present. Intersecondaries are more than half of subjacent secondaries and have a proximal and distal course parallel to major secondaries. Intercostal tertiary venation fabric is alternate percurrent. Epimedial tertiary fabric is reticulate. Aerolation has good development.

Remarks. The combination of characters seen in IP4 (marginal secondary present, parallel major secondaries, epimedial tertiary parallel to midvein and decurrent base) is shared with Myrtaceae.

\section{IP5 (Fig. 5f)}

Systematic affinity. Dicotyledonae Angiosperm; Order, Family, and Genus incertae sedis.

\section{Morphotype specimen. DPV-MHN-UNMSM-STRI-44002 (Fig. 5f1-4).}

Description. These fossil leaves are compound microphyll leaf impressions with nanophyll leaflets and toothed margin. Leaflets shape is ovate with a length of $1.12(0.7-1.53) \mathrm{cm}$ and a width of $0.81(0.64-0.97) \mathrm{cm}$. The lamina has medial symmetry and basal asymmetry. The apex has a convex shape and an obtuse angle and the base has a decurrent shape and an acute angle. The primary vein framework is pinnate, with one vein arising from the base. Major secondary veins are craspedodromous, excurrent with a spacing gradually increasing towards the proximal side of the leaf; the angle of attachment to midvein is smoothly decreasing proximally. Agrophic veins are simple, minor secondaries are parallel to major secondaries. The teeth are irregularly spaced with 5 teeth $/ \mathrm{cm}$. They occur in one order. The teeth are concave-concave in shape, and their sinuses are angular. Teeth exhibit a medial principal vein that terminates at the tooth apex.

Remarks. Due to the lack of preservation of the minor venation of this morphotype and the overlap of extant plant groups with similar leaf architecture, no possible taxonomic affinities for IP5 were proposed.

\section{Mollusks (Fig. 6a-g)}

At TAR-27, the mollusk assemblage is documented by well-preserved shells and dominated by gastropods. The single taxon recognized at the species level is the minute cochliopid gastropod Tryonia semituberculata Nuttall 1990 ( 1-2 mm-long). The assemblage also includes a fragment of an unidentified cerithioid, closely resembling Charadreon. Ampullariids are abundant and they contain at least two species: Ampullariidae indet. sp. 1, with a tall specimen $(>10 \mathrm{~cm})$, the shell surface of which contains spirally arranged pits; Ampullariidae indet. sp. 2, intermediate in size, with a wrinkled but otherwise smooth surface, is represented by eight shells. Planorbiids are the most abundant gastropods found at TAR-27. At least three species are referred to the planorbid genus Helisoma: Helisoma sp. 1 is high spired (two specimens); Helisoma sp. 2 is low-spired, small, and gyrauliform (six specimens); Helisoma sp. 3 is also low-spired, but taller and Planorbarius-shaped (four specimens). Bivalve shells are quite rare at TAR-27, but two isolated elliptical valves and one pair closely resemble those of the freshwater sphaeriid Eupera. They are provisionally assigned to ?Eupera sp. One specimen appears to be another freshwater sphaeriid referable to Musculium, a genus widespread in Holarctic and Neotropical rivers and lakes. Two other fragments are unidentifiable unionoids (Unionoidea indet.). 
In spite of our sampling efforts (excavation in-situ and screenwashing), the vertebrate record was particularly disappointing at Shumanza. We have only recover a few millimetric fish teeth, bones, coproliths, and broken scales in the black clays of TAR-27. These remains are referred to a large serrasalmine characiform (one tooth; similar to those of the living Colossoma from the Amazon basin; Fig. 6k) and unidentified Actinopterygii, documenting at least two morphs (pharyngeal teeth; Fig. 61-m). At the time being, there is no evidence of selachians (stingrays) or land vertebrates in the Shumanza section.

\section{Discussion}

Age constraints, biostratigraphy and tectono-sedimentary context

Most of plant taxa are not informative from a biostratigraphic point of view as they are long time living. However, some of the usual palynostratigraphic markers of northern Peru Palaeosantalaceaepites cingulatus (12.08-3.72), Echitricolporites spinosus (10.7-3.7 Ma), Grimsdalea magnaclavata (16.09-3.4 Ma), and Fenestrites longispinosus (10.06-1.18 Ma) (e.g. Lorente, 1986; Hoorn, 1993; Jaramillo et al., 2010) - have been recovered in the pollen sample TAR-27 (Figs 3 and 4). According to Leite's (2009) and Jaramillo et al.'s (2010, 2011) palynostratigraphic ranges, the co-occurrence of these taxa points to a late Miocene-early Pliocene age for the TAR-27 locality, with a 10.06-3.72 Ma range (Tortonian-Zanclean; Hilgen et al., 2012, fig. 29.11). The only fossil leaf morphotype that is informative is Malvaciphyllum which indicates a Late Miocene time. The mollusk of biostratigraphic interest is Tryonia semituberculata, a species reported from late early-early middle Miocene (Wesselingh et al., 2006; Wesselingh \& Ramos, 2010). Given this discrepancy, we assume that the occurrence of this Tryonia species in post-middle Miocene intervals represents a hitherto unknown extension. Given their poor record and fragmentary state, vertebrates do not allow for any biostratigraphical inference.

Although in a different environment, if we follow the sedimentation rates as hypothesized for the Pebas Formation by Roddaz et al. (2010, table 5.2), i.e. including the Ipururo Formation in the Subandean Zone of the northern Peruvian foreland basin, the fossil-documented stratigraphic interval at Shumanza could represent a 200-300 ka time slice, between TAR-52 and TAR-27.

In the Shumanza section, the Upper member of the Ipururo Fm., unconformably overlying the fossil-yielding interval, has been assigned to the late Miocene (Hermoza et al., 2005; Roddaz et al., 2010), likely to be related with the formation of the Subandean Zone, between 17 and $8 \mathrm{Ma}$ (Eude et al., 2015).

Accordingly, by coupling palynostratigraphy and local/regional lithostratigraphy, Shumanza fossil assemblages may be assigned an early late Miocene age, hypothetically ranging a 10.1ca. $8 \mathrm{Ma}$ interval.

\section{Paleoenvironmental reconstruction}

Palynological data show that the vegetation was dominated by angiosperms matching the results of van der Hammen and Hooghiemstra (2000) and Jaramillo et al. (2010, 2011).

Pollen and spores, gathered after similar ecological preferences (Fig. 7), suggest the dominance of riverine and alluvial environments, beside swamp forests and marshes between 10.1-8 Ma. 
In the upper Amazon river area Hoorn (1994a) identified mangrove pollen grains suggesting the influence of marine waters during the middle-late Miocene. We did not find any indication of mangrove environments and thus of marine incursion at TAR-27. Overall the marine to coastal layers are hard to find as they are usually centimeters thick and intercalated between freshwater deposits.

The great abundance of the green microalga Botryococcus co-occurring with in-situ charophytes (Fig. 6h-i), further points to freshwater conditions at TAR-27.

The fossil leaf assemblage collected from TAR-51 was deposited in a low energy alluvial environment that possibly represents a local community. We inferred low transport conditions given the completeness of most of the fossil leaves collected, e.g. presence of base and apex, and the preservation of compound leaves, that together with the fine-grained lithology of the layer is indicative of low-energy environments. Although the small number of leaf samples did not allow for quantitative paleoclimatic analyses, the complete description of these fossils may serve as a first approach for future studies of the leaf flora of the Huallaga basin. A comparison of the fossil morphotypes with the extant flora of the region allowed us to propose best-guest family level affinities of three of the morphotypes, and suggests that there is possibly some degree of resemblance to the extant flora. However, more sampling and comparisons are needed to support this preliminary hypothesis. The new record of Malvaciphyllum $\mathrm{sp}$. in this locality supports the well-known presence of this group in the Neotropical region (Jaramillo et al., 2010; Carvalho et al., 2011) and agrees with the Bombacoideae pollen grains found at TAR-27.

The mollusk fauna with delicate shell surfaces (e.g. Eupera sp., Fig. 6a) indicating no transport post-mortem, represents a low-energy environment with strict freshwater conditions. Ampullariids further indicate swamp conditions. The remaining species are indicative of permanent shallow conditions with rich peripheral vegetation whereas the occurrence of unionoids suggests a certain level of oxygenation. The mollusk assemblage may have lived in a semi-isolated oxbow lake. Moreover, their preservation resembles very much the MZ2 La Tagua Beds preservation of Colombia, in the early phases of the Pebas Mega-Wetland System (Wesselingh et al., 2006; Wesselingh \& Ramos, 2010).

The sedimentary facies of the Middle Member of the Ipururo Formation at Shumanza combined with the vegetation, mollusk, algae, charophyte, and vertebrate assemblages documented at TAR-27, are consistent with the long lasting existence of a slowly-streaming river in a fluvio-lacustrine depositional environment, in a lowland landscape shaped into swamping forests, marshes and alluvial/riparian forests ca. 8-10 million years ago.

\section{General discussion}

The fossil and sedimentary records of TAR-27 testify to the dominance of stable riverine/alluvial forests and to the persistence of a steady lowland rainforest close to the Andes between 10 and $8 \mathrm{Ma}$ (Fig. 7). The presence of mountain taxa occurring in low abundance in this site (Fig. 7) is indicative of some mountainous terrain in the river drainage area. However, we did not observe characteristic high-altitude taxa such as Podocarpus, Hedyosmum, Jamesonia, or Polylepis (Graham et al., 2001; Marchant et al., 2002) which were present both in the upper Amazon River area and in the Amazon Fan during the latest Miocene to Pliocene (Hoorn, 1994b; Hoorn et al., 2017). The TAR-27 site, situated more to the South (Fig. 1), possibly received sediments and organic matter (including pollen and spores) from a different drainage basin than the upper Amazon River (see paleogeographic maps in Hoorn et al., 2010).

Recent geochemical and palynological work on sediments of the Amazon submarine fan (Hoorn et al., 2017) has shown that the earliest Andes-derived sediments occurred during the late Miocene and that the onset of the transcontinental Amazon River took place between 9.4 and $9 \mathrm{Ma}$. This time interval also coincides with the progressive demise of the Pebas MegaWetland System in northwestern South America, in favor of the fluvial-influenced Acre System (for a review, see Salas-Gismondi et al., 2015; Antoine et al., 2016, 2017). This is consistent 
with our paleovegetation data indicative of the absence of mangrove and the lack of any marine input in the Shumanza record. However, new paleontological and lithological surveys would be needed to confirm the absence of both mangrove and typical high-elevation taxa in the Shumanza region.

\section{Compliance with ethical standards}

Conflict of interest: The authors declare that we have no conflict of interest

Ethical approval: This article does not contain any studies with human participants or living animals performed by any of the authors.

\section{Acknowledgements}

We deeply thank Marie-Pierre Ledru (ISEM, Montpellier) and Carina Hoorn (University of Amsterdam) for their invaluable help to identify the palynomorphs. We especially thank Laurent Marivaux, Myriam Boivin (ISEM), François Pujos (IANIGLA-CONICET, Mendoza), and especially Patrice Baby (GET, Toulouse) for their assistance in the field. Fieldwork was funded by the National Geographic Society and by French Connection Films, under an agreement between the Museo de Historia Natural de la Universidad Nacional de San Marcos, Lima, and the ISEM-University of Montpellier, France. This work was further funded by COOPINTEER CNRS/CONICET and ECOS-SUD/FONCyT international collaboration programs and through an "Investissements d'Avenir" grant managed by the "Agence Nationale de la Recherche" (CEBA, ANR-10-LABX-0025-01). AFT was granted by the CEBA for his stay in the Institute for Biodiversity and Ecosystem Dynamics, Amsterdam University. CM acknowledges Harold E. Moore Jr. Memorial and Endowment Funds from Cornell University, and the doctoral fellowship of Fulbright-Colciencias. We warmly thank M. di Pasquo, D. Kadolsky, and a third anonymous referee who greatly helped us to improve previous versions of the manuscript. This is ISEM publication $\mathrm{n}^{\circ} 2019-176$.

\section{References}

Antoine, P.-O., Abello, M. A., Adnet, S., Sierra, A. J. A., Baby, P., Billet, G., Boivin, M., Calderón, Y., Candela, A., Chabain, J., Corfu, F., Croft, D.A., Ganerød, M., Jaramillo, C., Klaus, S., Marivaux, L., Navarrete, R.E., Orliac, M.J., Parra, F., Pérez, M.E., Pujos, F., Rage, J.-C., Ravel, A., Robinet, C., Roddaz, M., Tejada-Lara, J.V., Vélez-Juarbe, J., Wesselingh, F.P., \& Salas-Gismondi, R. (2016). A 60-million-year Cenozoic history of western Amazonian ecosystems in Contamana, eastern Peru. Gondwana Research, 31, 30-59.

Antoine, P.-O., Salas-Gismondi, R., Pujos, F., Ganerød, M., \& Marivaux, L. (2017). Western Amazonia as a hotspot of mammalian biodiversity throughout the Cenozoic. Journal of Mammalian Evolution, 24, 5-17.

Armijo, R., Lacassin, R., Coudurier-Curveur, A., \& Carrizo, D. (2015). Coupled tectonic evolution of Andean orogeny and global climate. Earth-Science Reviews, 143, 1-35.

Barreto, C. F., Neto, J. A. B., Vilela, C. G., \& Barth, O. M. (2015). Palynological studies of Late Holocene Jurujuba Sound sediments (Guanabara Bay), Rio de Janeiro, southeast Brazil. Catena, 126, 20-27.

Batten, D. J. \& Grenfell, H. R. (1996). Botryococcus. In J. Jansonius \& D.C. McGregor (Eds.), Palynology: principles and applications (pp. 205-214), American Association of Stratigraphic Palynologists Foundation, 1.

Bershaw, J., Garzione, C.N., Higgins, P., MacFadden, B., Anaya, F., \& Alvarenga, H. (2010). Spatial-temporal changes in Andean plateau climate and elevation from stable isotopes of mammal teeth. Earth and Planetary Science Letters, 289, 530-538.

Boonstra, M., Ramos, M. I. F., Lammertsma, E. I., Antoine, P.-O., \& Hoorn, C. (2015). Marine connections of Amazonia: evidence from foraminifera and dinoflagellate cysts (early to middle Miocene, Colombia/Peru). Palaeogeography, Palaeoclimatology, Palaeoecology, 417, 176-194.

Campbell, K. E., Heizler, M., Frailey, C. D., Romero-Pittman, L., \& Prothero, D. R. (2001). Upper Cenozoic chronostratigraphy of the southwestern Amazon Basin. Geology, 29, 595-598.

Carvalho, M.R., Herrera, F.A., Jaramillo, C.A., Wing, S.L., \& Callejas, R. (2011). Paleocene Malvaceae from northern South America and their biogeographical implications. American Journal of Botany, 98, 1337-1355.

Cole, T.C.H., Bachelier, J.B., \& Hilger, H.H. (2018). Tracheophytes Phylogeny Poster. Vascular plants: Systematics and Characteristics. PeerJ Preprints, 7:e2614v3. doi:10.7287/peerj.preprints.2614v3/supp-1

Cole, T.C.H., Hilger, H.H., \& Stevens, P.F. (2019). Angiosperm Phylogeny Poster. Flowering Plant Systematics. PeerJ Preprints, 7:e2320v5. doi: 10.7287/peerj.preprints.2320v5/supp-1.

Colinvaux, P. A., De Oliveira, P.E., \& Moreno Patiño, J.E.M. (1999). Amazon Pollen Manual and AtlasManual e Atlas Palinológico da Amazônia. Amsterdam, Harwood Academic Publishers, 322 p.

da Silva-Caminha, S. A., Jaramillo, C. A., \& Absy, M. L. (2010). Neogene palynology of the Solimões basin, Brazilian Amazonia. Palaeontographica Abteilung B, 284, 13-79.

D’Apolito, C. (2016). Landscape evolution in western Amazonia: palynostratigraphy, palaeoenvironments and diversity of the Miocene Solimões Formation, Brazil. Unpublished PhD thesis, Univ. Birmingham, UK, 365 p. 
Ellis, B., Daly, D.C., Hickey, L.J., Mitchell, J.V., Johnson, K.R., Wilf, P., \& Wing, S.L. (2009) Manual of Leaf Architecture. Cornell University Press, Ithaca, NY.

Eude, A., Roddaz, M., Brichau, S., Brusset, S., Calderon, Y., Baby, P., \& Soula, J.-C., 2015. Controls on timing of exhumation and deformation in the northern Peruvian eastern Andean wedge as inferred from low-temperature thermochronology and balanced cross section. Tectonics, 34, 715-730.

Figueiredo, J., Hoorn, C., \& Ven, P. van der. \& Soares, E. (2009). Late Miocene onset of the Amazon River and the Amazon deep-sea fan: Evidence from the Foz do Amazonas Basin. Geology, 37, 619-622.

Goillot, C. (2010). Biochronologie (vertébrés, pollen) et paléogéographie du bassin amazonien occidental au Miocène moyen. Unpublished PhD Thesis, Univ. Toulouse, France, 250 p..

Gorini, C., Haq, B.U., dos Reis, A.T., Silva, C.G., Cruz, A., Soares, E., \& Grangeon, D. ( 2014). Late Neogene sequence stratigraphic evolution of the Foz do Amazonas Basin, Brazil. Terra Nova, 26, 179-185.

Graham, A. (2009). The Andes: a geological overview from a biological perspective. Annals of the Missouri Botanical Garden, 96(3), 371-385.

Graham, A., Gregory-Wodzicki, K.M., Wright, K.L. (2001). Studies in Neotropical Paleobotany. XV. A MioPliocene palynoflora from the Eastern Cordillera, Bolivia: implications for the uplift history of the Central Andes. American Journal of Botany, 88(9), 1545-1557.

Guy-Ohlson, D. (1992). Botryococcus as an aid in the interpretation of palaeoenvironment and depositional processes. Review of Paleobotany and Palynology, 71, 1-15.

Herrera, L.F. \& Urrego, L.E. (1996). Atlas de polen de plantas útiles y cultivadas de la Amazonia colombiana (Pollen atlas of useful and cultivated plants in the Colombian Amazon region). Estudios en la Amazonia Colombiana, 11, Bogotá: Tropenbos-Colombia. 462 p.

Hermoza, W., Brusset, S., Baby, P., Gil, W., Roddaz, M., Guerrero, N., \& Bolaños, R. (2005). The Huallaga foreland basin evolution: Thrust propagation in a deltaic environment, northern Peruvian Andes. Journal of South American Earth Sciences, 19, 21-34.

Hilgen, F.J., Lourens, L.J., \& Van Dam, J.A. (2012). The Neogene period. In F. Gradstein, J. Ogg, M. Schmitz, \& G. Ogg (Eds.), The Geologic Time Scale 2012 (pp. 923-978). Boston: Elsevier.

Hooghiemstra, H. (1984). Vegetation and Climatic History of the High Plain of Bogota, Colombia: A Continuous Record of the Last 3.5 Million Years. J. Cramer Hardcover - A Squared Books (Don Dewhirst). Dissertationes Botanicae, 79, 368 p.

Hoorn, C. (1993). Marine incursions and the influence of Andean tectonics on the Miocene depositional history of northwestern Amazonia: results of a palynostratigraphic study. Palaeogeography, Palaeoclimatology, Palaeoecology, 105, 267-309.

Hoorn, M. C. (1994a). Miocene palynostratigraphy and palaeo-environments of northwestern Amazonia: Evidence for marine incursions and the influence of Andean tectonics. Unpublished $\mathrm{PhD}$ thesis in Palynology and Paleo/Actuo-ecology, University of Amsterdam, Amsterdam, 156 p.

Hoorn, C. (1994b). An environmental reconstruction of the palaeo-Amazon river system (Middle-Late Miocene, NW Amazonia). Palaeogeography, Palaeoclimatology, Palaeoecology, 112, 187-238.

Hoorn, C. (2006). Mangrove forests and marine incursions in Neogene Amazonia (lower Apaporis River, Colombia). Palaios, 21, 197-209.

Hoorn, C., Wesselingh, F.P., ter Steege, H., Bermudez, M.A., Mora, A., Sevink, J., Sanmartín, I., SánchezMéseguer, A., Anderson, C.L., Figueiredo, J.P., Jaramillo, C., Riff , D., Negri, F.R., Hooghiemstra, H., Lundberg, J., Stadler, T., Särkinen, T., \& Antonelli, A. (2010). Amazonia through time: Andean uplift, climate change, landscape evolution, and biodiversity. Science, 330, 927-931.

Hoorn, C., Bogotá-A, G.R., Romero-Baez, M., Lammertsma, E.I., Flantua, S.G.A., Dantas, E.L., Dino, R., do Carmo, D.A., \& Chemale, F. Jr. (2017). The Amazon at sea: Onset and stages of the Amazon River from a marine record, with special reference to Neogene plant turnover in the drainage basin. Global Planet Change, 153, 5165.

Horton, B.K. (2018). Sedimentary record of Andean mountain building. Earth-Science Reviews, 178, $279-309$.

Hulka, C. \& Heubeck, C. (2010). Composition and Provenance History of Late Cenozoic Sediments in Southeastern Bolivia: Implications for Chaco Foreland Basin Evolution and Andean Uplift. Journal of Sedimentary Research, 80, 288-299.

Jaramillo, C., Hoorn, C., Silva, S. A. F., Leite, F., Herrera, F., Quiroz, L., Dino, R., \& Antonioli, L. (2010). The origin of the modern Amazon rainforest: implications of the palynological and palaeobotanical record. In C. Hoorn and F.P. Wesselingh (Eds.), Amazonian landscape and species evolution: a look into the past (pp. 317334). Blackwell-Wiley Publishing: Hoboken.

Jaramillo, C. A., Rueda, M., \& Torres, V. (2011). A palynological zonation for the Cenozoic of the Llanos and Llanos Foothills of Colombia. Palynology, 35, 46-84.

Jaramillo, C.A. \& Rueda, M. (2016). A morphological electronic database of Cretaceous-Tertiary fossil pollen and spores from northern South America. Colombian Petroleum Institute \& Smithsonian Tropical Research. Available at: http://biogeodb.stri.si.edu/jaramillo/palynomorph/

Jaramillo, C., Romero, I., Bayona, G., Duarte, E., Louwye, S., Escobar, J., Luque, J., Zapata, V., Mora, A., Schouten, S., Zavada, M., Harrington, G., Ortiz, J., \& Wesselingh, F.P. (2017). Miocene flooding events of western Amazonia. Science Advances, 3, 1-12. 
Kar, N., Garzione, C. N., Jaramillo, C., Shanahan, T., Carlotto, V., Pullen, A., Moreno, F., Anderson, V., Moreno, E., \& Eiler, J. (2016). Rapid regional surface uplift of the northern Altiplano plateau revealed by multiproxy paleoclimate reconstruction. Earth and Planetary Science Letters, 447, 33-47.

Latrubesse, E. M., Cozzuol, M., da Silva-Caminha, S. A., Rigsby, C. A., Absy, M. L., \& Jaramillo, C. (2010). The Late Miocene paleogeography of the Amazon Basin and the evolution of the Amazon River system. EarthScience Reviews, 99, 99-124.

Leite, F.P.R. (2009). Palinogia da formação Solimões, neógeno da Bacia do Solimões, Estado do Amazonas, Brasil: implicações paleoambientais e bioestratigráficas. Unpublished Thesis. 128 p. http://repositorio.unb.br/handle/10482/2475?mode=full.

Lorente, M. (1986). Palynology and palynofacies of the Upper Tertiary in Venezuela. Berlin, J. Cramer, 222 p.

Lundberg, J.G., Sabaj Pérez, M.H., Dahdul, W.M. \& Aguilera, O.A. (2010). The Amazonian Neogene fish fauna. In C. Hoorn and F.P. Wesselingh (Eds.), Amazonian landscape and species evolution: a look into the past (pp. 281-301). Blackwell-Wiley Publishing: Hoboken.

Marchant, R., Almeida, L., Behling, H., Berrio, J. C., Bush, M., Cleef, A., Duivenvoorden, J., Kapelle, M., De Oliveira, P., Teixeira de Oliveira-Filho, A., Lozano-Garcia, S., Hooghiemstra, H., Ledru, M.-P., LudlowWiechers, B., Markgraf, V., Mancini, V., Paez, M., Prieto, A., Rangel, O., \& Salgado-Labouriau, M.L. (2002). Distribution and ecology of parent taxa of pollen lodged within the Latin American Pollen Database. Review of Palaeobotany and Palynology, 121, 1-75.

Medeanic, S. (2006). Freshwater algal palynomorph records from Holocene deposits in the coastal plain of Rio Grande do Sul, Brazil. Review of Palaeobotany and Palynology, 141, 83-101.

Mora, A., Baby, P., Roddaz, M., Parra, M., Brusset, S., Hermoza, W. \& Espurt, N. (2010). Tectonic history of the Andes and subAndean zones: Implications for the development of the Amazon drainage basin. In C. Hoorn and F.P. Wesselingh (Eds.), Amazonian landscape and species evolution: a look into the past (pp. 38-60). Blackwell-Wiley Publishing: Hoboken.

Negri, F.R., Bocquentin-Villanueva, J., Frerigolo, J. \& Antoine, P.-O. (2010). A review of Tertiary mammal faunas and birds from western Amazonia. In C. Hoorn and F.P. Wesselingh (Eds.), Amazonian landscape and species evolution: a look into the past (pp. 245-258). Blackwell-Wiley Publishing: Hoboken.

Paleosedes, 2015. Bioestratigrafía mediante palinología. Muestras de superficie, Tarapoto (Perú, Suramérica). Unpublished Report, REP-1008-16-01-2015, pp. 1-5.

Peppe, D.J., Hickey, L.J., Miller, I.M., \& Green, W.A. (2008) A Morphotype Catalogue, Floristic Analysis and Stratigraphic Description of the Aspen Shale Flora (Cretaceous-Albian) of Southwestern Wyoming. Bulletin of the Peabody Museum of Natural History, 49, 181-208.

Punt, W., Hoen, P. P., Blackmore, S., Nilsson, S. \& Le Thomas, A. (2007). Glossary of pollen and spore terminology. Review of Palaeobotany and Palynology, 143, 1-81.

Räsänen, M.E., Linna, A.M., Santos, J.C.R. \& Negri, F.R. (1995) Late Miocene tidal deposits in the Amazonian foreland basin. Science 269, 386-90.

Ribeiro, A.M., Madden, R.H., Negri, F.R., Kerber, L., Hsiou, A.S. \& Rodrigues, K.A. (2013). Mamíferos fósiles y biocronología en el suroeste de la Amazonia, Brasil. In: D. Brandoni \& J.I. Noriega (Eds.), El Neógeno de la Mesopotamia argentina, Asociación Paleontológica Argentina, Publicación Especial 14, pp. $207-221$.

Riff, D., Romano, P.S.R., Oliveira, G.R., \& Aguilera, O.A. (2010). Neogene crocodile and turtle fauna in northern South America. In C. Hoorn and F.P. Wesselingh (Eds.), Amazonian landscape and species evolution: a look into the past (pp. 259-280). Blackwell-Wiley Publishing: Hoboken.

Roddaz, M., Viers, J., Brusset, S., Baby, P., \& Hérail, G. (2005). Sediment provenances and drainage evolution of the Neogene Amazonian foreland basin. Earth and Planetary Science Letters, 239, 57-78.

Roddaz, M., Hermoza, W., Mora, A., Baby, P., Parra, M., Christophoul, F., Brusset, S., \& Wesselingh, F. P. (2010). Cenozoic sedimentary evolution of the Amazonian foreland basin system. In C. Hoorn and F.P. Wesselingh (Eds.), Amazonian landscape and species evolution: a look into the past (pp. 361-388). Blackwell-Wiley Publishing: Hoboken.

Roubik, D. W. \& Moreno, P. (1991). Pollen and spores of Barro Colorado Island (Panama). Monographs in Systematic Botany, 36, 270 p.

Salas-Gismondi, R., Flynn, J. J., Baby, P., Tejada-Lara, J. V., Wesselingh, F. P., \& Antoine, P. O. (2015). A Miocene hyperdiverse crocodylian community reveals peculiar trophic dynamics in proto-Amazonian megawetlands. Proceedings of the Royal Society of London B: Biological Sciences, 282, 20142490.

Sánchez Fernández, A.W. \& Herrera Tufino, I. (1998). Geología de los cuadrángulos de Moyobamba, Saposoa y Juanjui. Hojas 13-j, 14-j y 15-j. Boletín del Instituto Geológico, Minero y Metalúrgico del Perú, A-122, 1-269.

Sánchez Izquierdo, J., Álvarez Cumpa, D. \& Lagos Manrique, A. (1998). Geología de los cuadrángulos de Juscusbamba y Pólvora. Hojas 16-i y 16-j. Boletín del Instituto Geológico, Minero y Metalúrgico del Perú, A-119, 1-268.

Suc, J.-P., Fauquette, S. \& Popescu, S. M. (2004). L'investigation palynologique du Cénozoïque passe par les herbiers. In Actes du Colloque "Les herbiers: un outil d'avenir. Tradition et modernité", Villeurbanne. Edit. Association française pour la Conservation des Espèces Végétales, Nancy (pp. 67-87). 
Teunissen van Manen, M. (2015a). Miocene Amazonian Palynological Diversity - Image files. figshare. http://dx.doi.org/10.6084/m9.figshare.1396453

Teunissen van Manen, M. (2015b). Miocene Amazonian palynological diversity database - Entries record. figshare. http://dx.doi.org/10.6084/m9.figshare.1396562

Van Der Hammen, T. \& Hooghiemstra, H. (2000). Neogene and Quaternary history of vegetation, climate, and plant diversity in Amazonia. Quaternary Science Reviews, 19, 725-742.

Van Soelen, E.E., Kim, J.-H., Santos, R.V., Dantas, E.L., Vasconcelos de Almeida, F., Pires, J.P., Roddaz, M., \& Sinninghe Damsté, J.S. (2017). A 30 Ma history of the Amazon River inferred from terrigenous sediments and organic matter on the Ceará Rise. Earth and Planetary Science Letters, 474, 40-48

Wesselingh, F.P., Hoorn, M.C., Guerrero, J., Räsänen, M., Romero Pittmann, L., \& Salo, J. (2006). The stratigraphy and regional structure of Miocene deposits in western Amazonia (Peru, Colombia and Brazil), with implications for late Neogene landscape evolution. Scripta Geologica, 133, 291-322.

Wesselingh, F.P. \& Ramos, M.I.F. (2010). Amazonian aquatic invertebrate faunas (Mollusca, Ostracoda) and their development over the past 30 million years. In C. Hoorn and F.P. Wesselingh (Eds.), Amazonian landscape and species evolution: a look into the past (pp. 302-316). Blackwell-Wiley Publishing: Hoboken. 


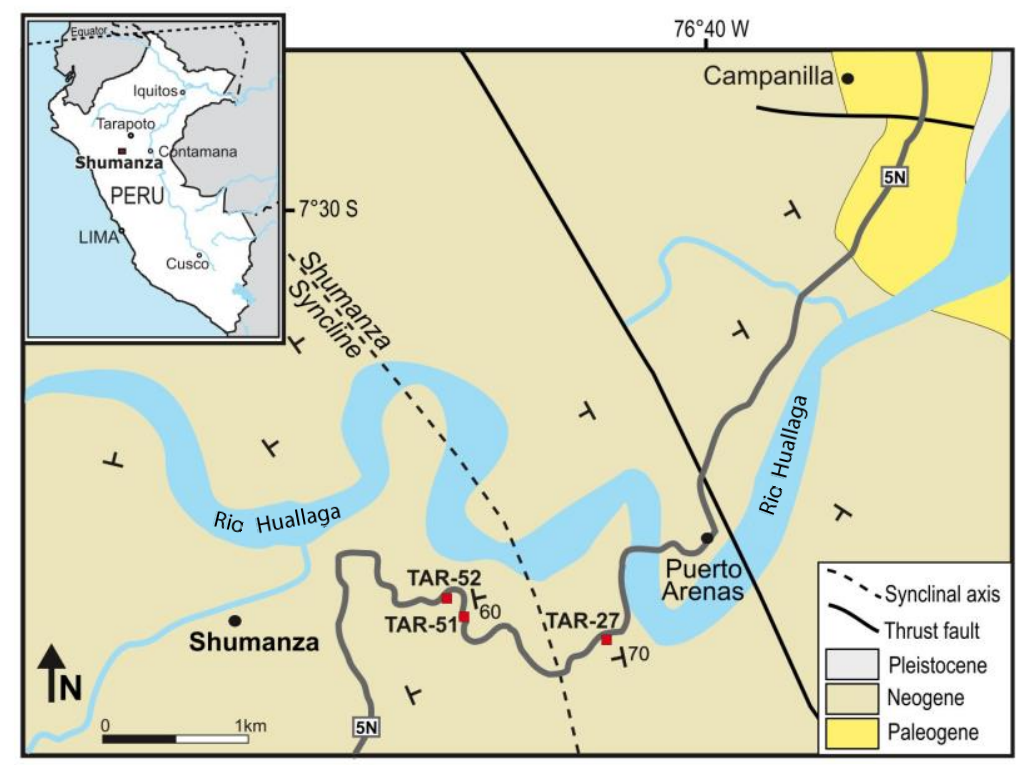

Fig. 1. Location map of the studied localities, Shumanza section, Huallaga Basin, San Martín Department, Peru. Simplified geological map adapted from Sánchez Fernández and Herrera Tufino (1998) and Sánchez Izquierdo et al. (1998).
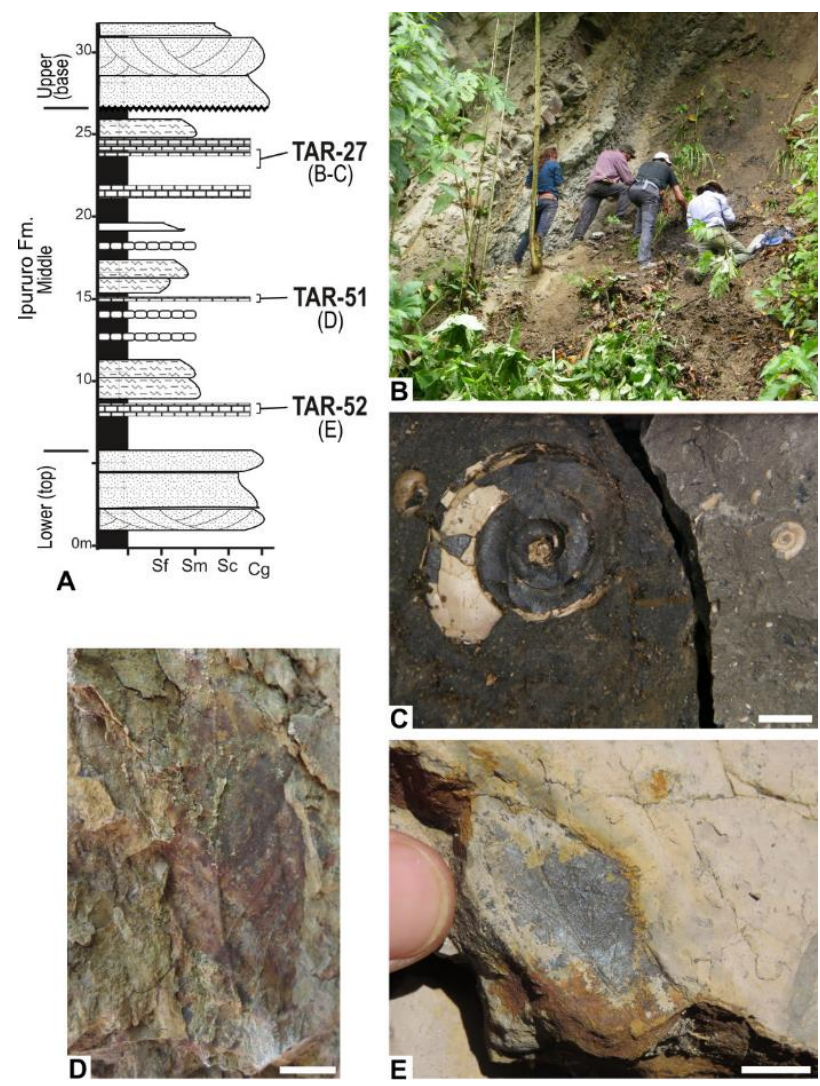

Fig. 2. Late Miocene fossil-yielding localities, Shumanza section, Huallaga Basin, San Martín Department, Peru. a Location of fossil yielding localities in the measured section (modified from Hermoza et al. 2005). Only TAR27 yielded palynomorphs. M, marls; Sf, fine grained sandstone; Sm, medium-grained sandstone; Sc, coarsegrained sandstone; $\mathrm{Cg}$, conglomerate. Brick-like designs denote limestones. b General view of TAR-27. c Detailed view of the gastropod-rich lignitous clays at TAR-27. d Detail of the leaf-yielding facies at TAR-51. e Detail of the leaf-yielding facies at TAR-52. Scale bars equal $10 \mathrm{~mm}$. 

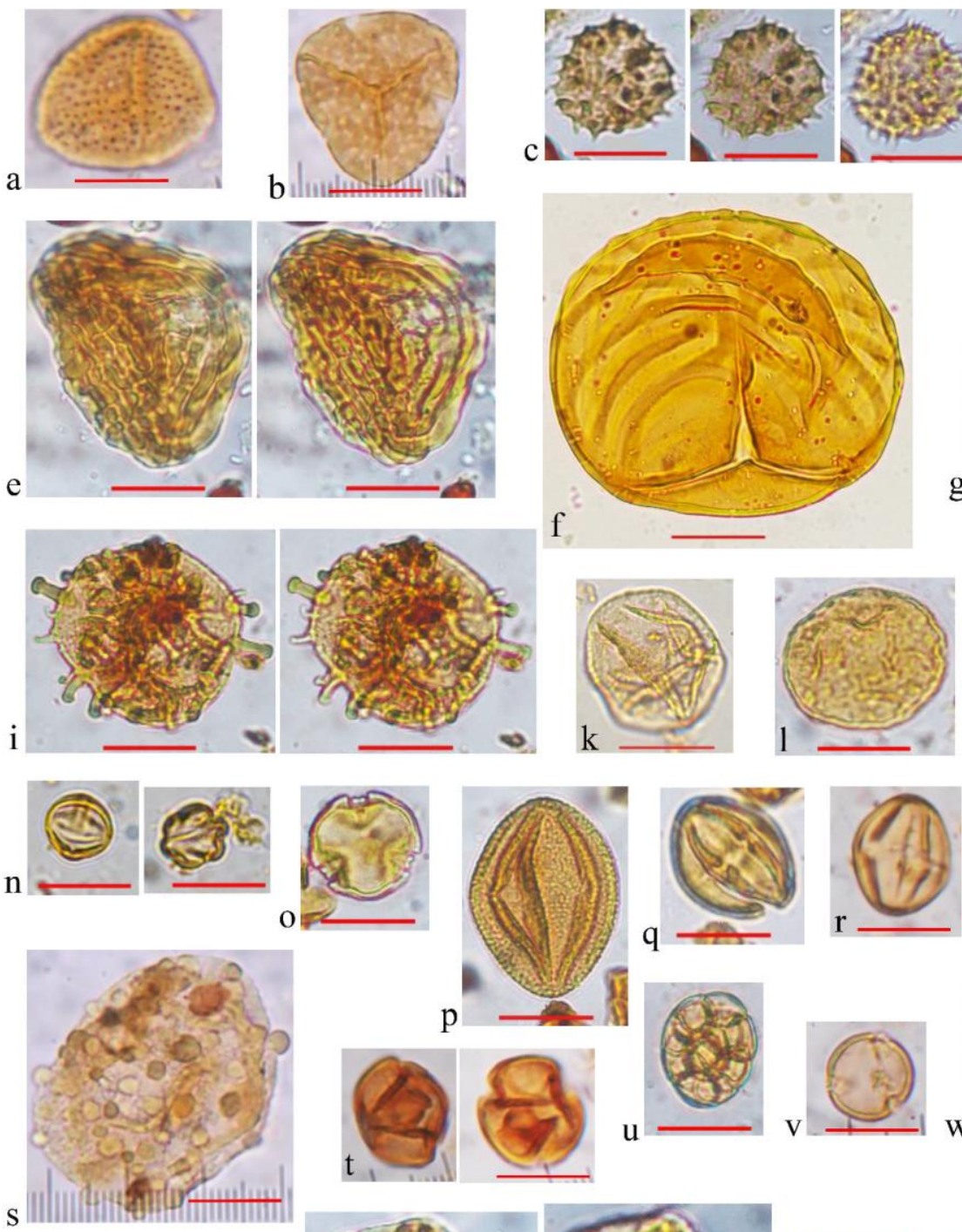

,
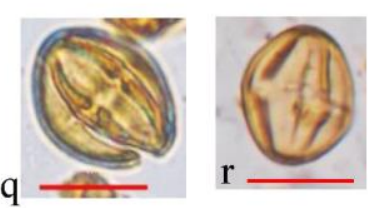

g
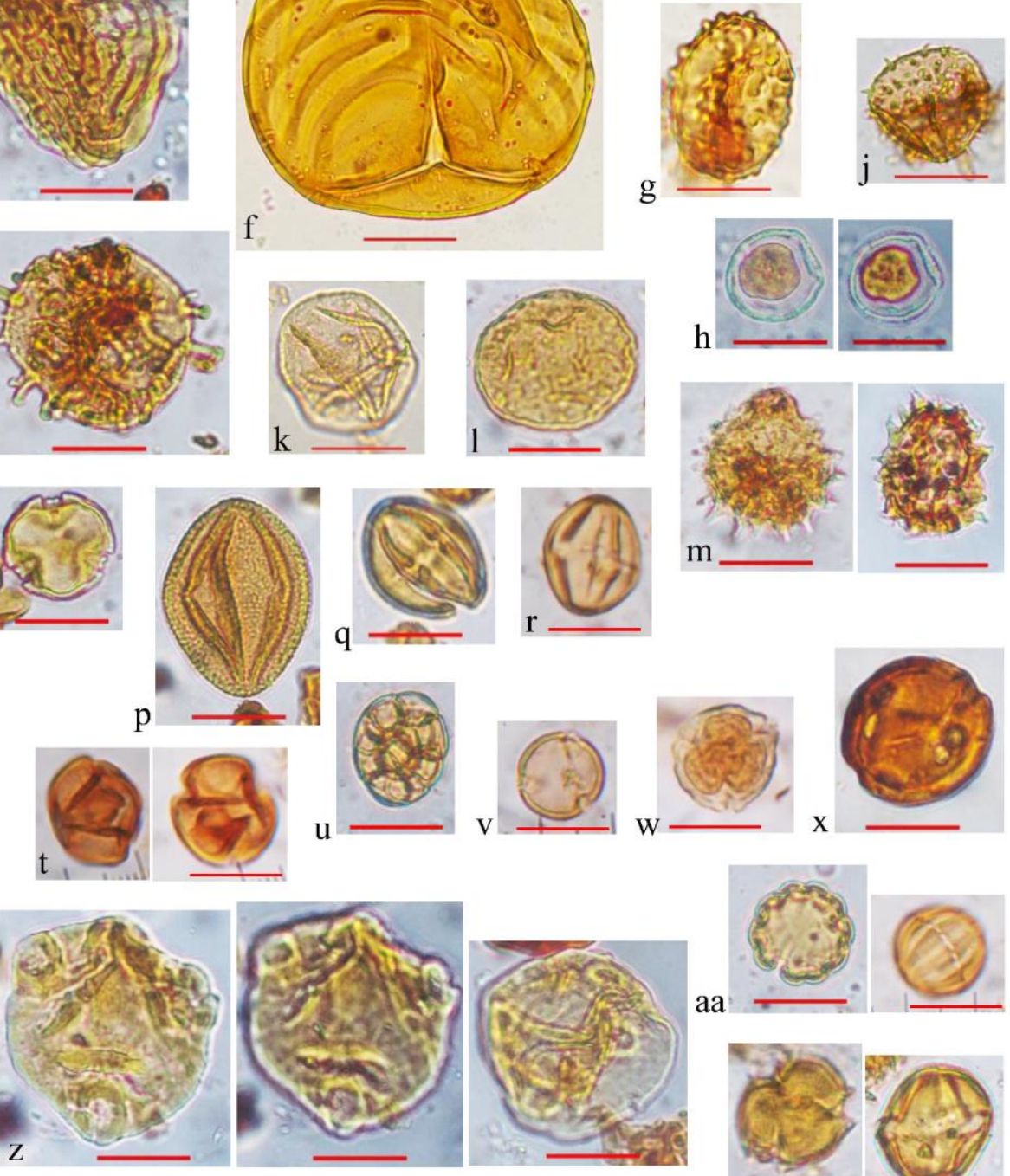

$\mathrm{cc}$
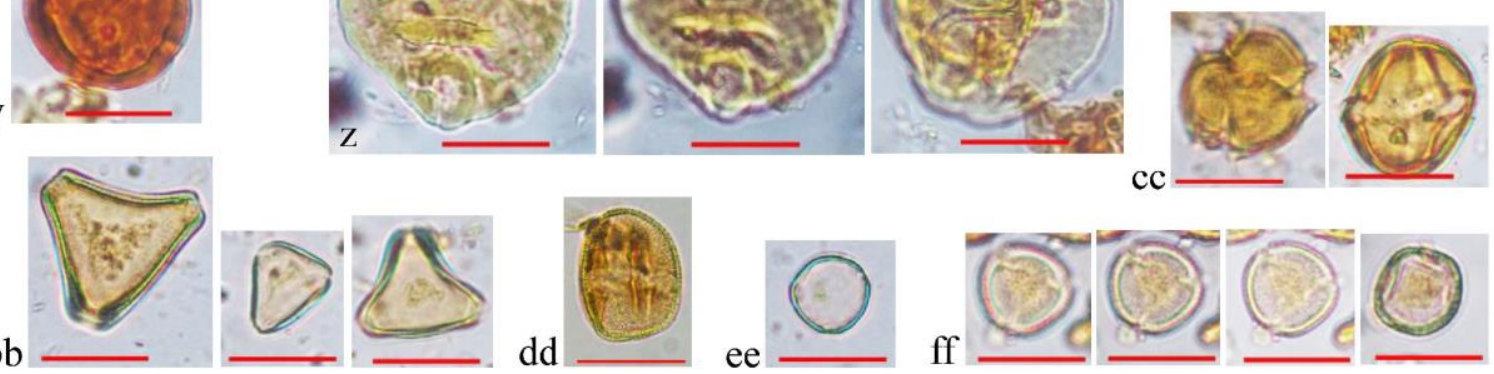

Fig. 3. Spores and pollen grains from the late Miocene TAR-27 locality, Shumanza section, Huallaga Basin, San Martín Department, Peru. Spores, Lycophytes: a Lycopodium foveolate (Lycopodiaceae); b Lycopodium sp. (Lycopodiaceae); c Selaginella sp. (Selaginellaceae); Spores, Monilophytes: d Cyathea (Cyatheaceae); e Pityrogramma sp. (Pteridaceae, Polypodiales); f Ceratopteris sp. (Parkeriaceae, Polypodiales); g Polypodiaceae (Polypodiales). Pollen grains, Angiosperm monocots: h Anthurium sp. (Araceae); i Grimsdalea magnaclavata (Arecaceae); j Mauritia sp. (Arecaceae); k Cyperaceae; 1 Marantaceae. Pollen grains, Angiosperm eudicots: m Echitricolpites spinosus (Asteraceae); n Combretaceae/Melastomataceae; o Alchornea sp. (Euphorbiaceae); p Sapium sp. (Euphorbiaceae); q Euphorbiaceae; r Fabaceae; s Bauhinia acuminata (Fabaceae Caesalpiniaceae); $\mathrm{t}$ Cassia sp. (Fabaceae Caesalpiniaceae); u Fabaceae Mimosoideae; v Flacourtiaceae; w Byrsonima sp.

(Malpighiaceae); x Tetrapterys sp. (Malpighiaceae); y Stigmaphyllon sp. (Malpighiaceae); z Ludwigia sp. (Onagraceae); aa Polygalaceae; bb Proteaceae; cc Faramea sp. (Rubiaceae); dd Rubiaceae; ee Urticaceae/Moraceae; ff Verbenaceae. Systematics follows Cole et al. (2018, 2019). Scale bars equal $20 \mu \mathrm{m}$. 

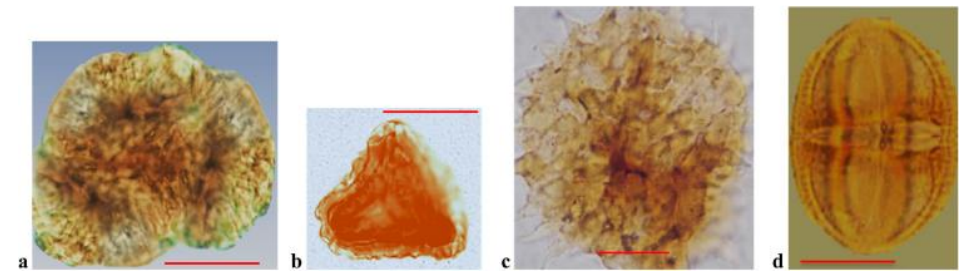

Fig. 4. Algae, spores, and pollen grains of interest, from the late Miocene TAR-27 locality, as found in a preliminary sample (Paleosedes 2015). Chlorophyta: a Botryococcus (Botryococceae), colony. Spores, Lycophytes: b Cingulatisporites sp. (Selaginellaceae) (EF F41/2). Pollen grains, Angiosperm eudicots: c Fenestrites longispinosus (Asteraceae) (EF K14/4). d Palaeosantalaceaepites cingulatus (Euphorbiaceae) (EF G24/4). EF = English Finder. Scale bars equal $20 \mu \mathrm{m}$.
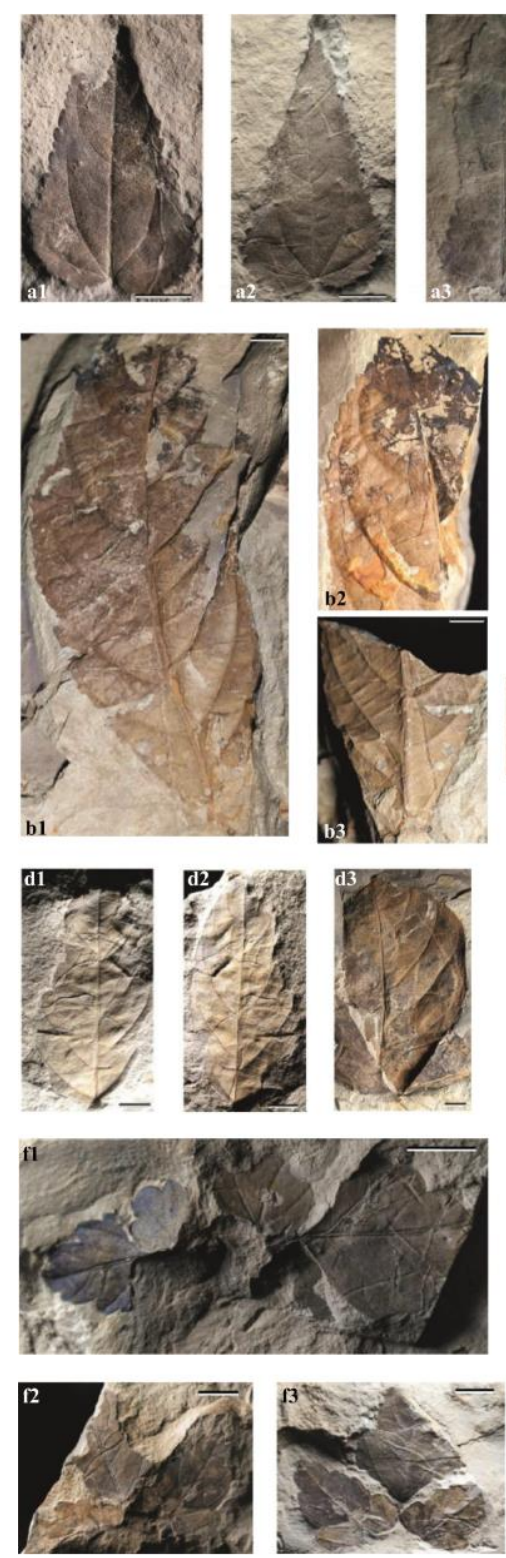
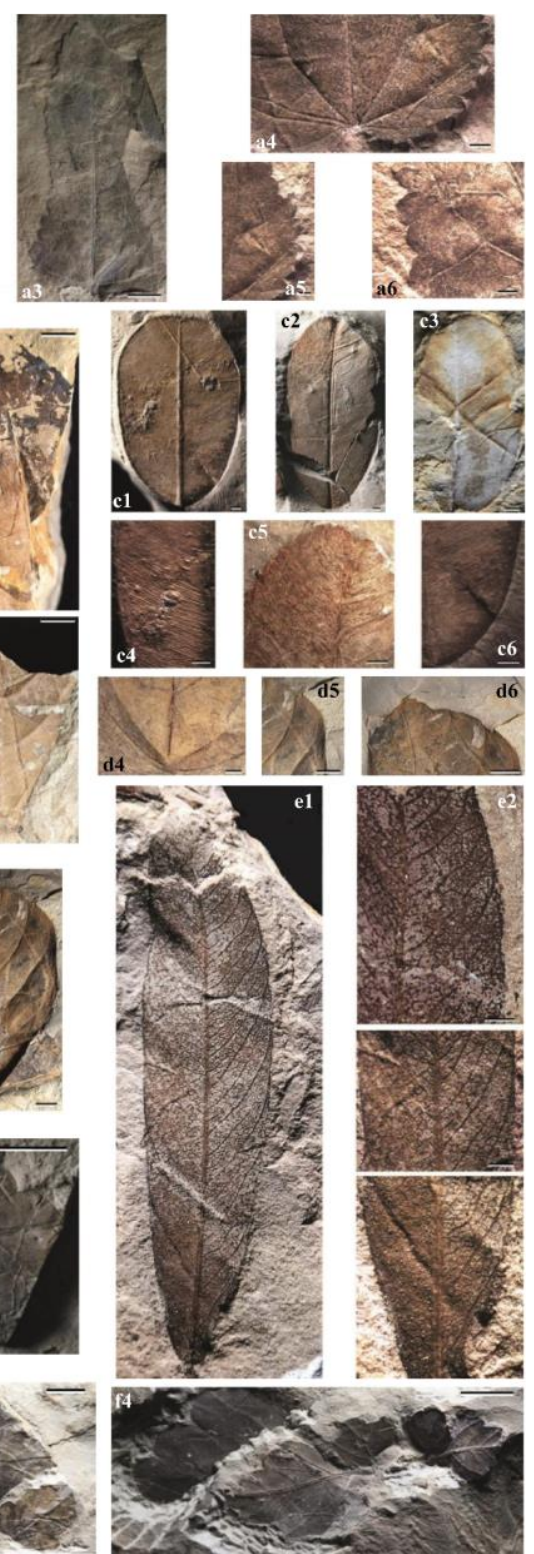

Fig. 5. Late Miocene leaf impressions from TAR-51 locality (STRI 110057), Shumanza section, Huallaga Basin, San Martín Department, Peru. a Malvaciphyllum sp. (DPV-MHN-UNMSM-STRI-41430; 43993; 43994). b IP1, dicotyledonae of uncertain affinities, resembling Caryocaraceae (DPV-MHN-UNMSM-STRI-413995). c IP2, dicotyledonae of uncertain affinities, resembling Fabaceae (DPV-MHNUNMSM- STRI-43996; 413997; 43998). d IP3, dicotyledonae of uncertain affinities (DPV-MHN-UNMSM-STRI-43999; 44000). e IP4, Dicotyledonae of uncertain affinities, resembling Myrtaceae (DPVMHN- UNMSM-STRI-44001); f IP5, dicotyledonae of uncertain affinities (DPV-MHN-UNMSM-STRI-44002). Scale bars equal $5 \mathrm{~mm}$ (a-c, e-f) and $1 \mathrm{~mm}$ (d). 


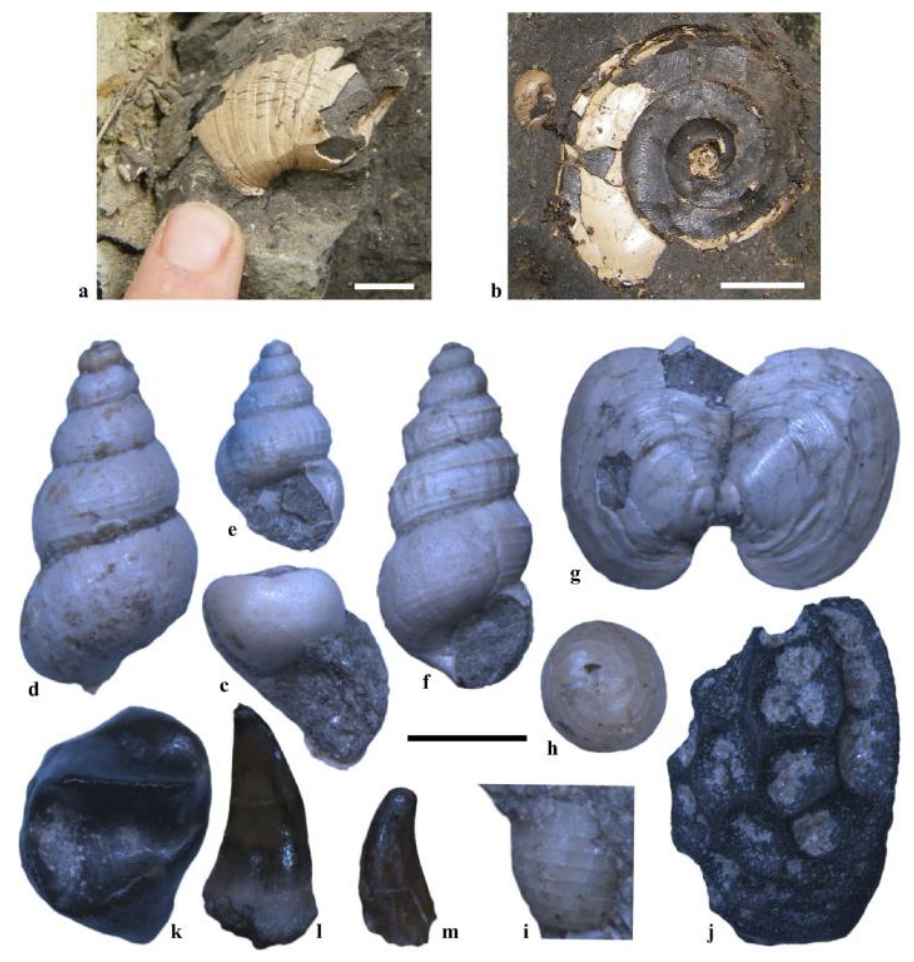

Fig. 6. Mollusks, charophytes, fruit shell, and vertebrates from the late Miocene TAR-27 locality, Shumanza section, Huallaga Basin, San Martín Department, Peru. a-g mollusks. a Ampullariidae indet. sp. 1 (large-sized). b Helisoma sp. 3 (large-sized, Planorbarius-like). C Ampullariidae indet. sp. 2 (small-sized). d Cochliopidae indet. E Cochliopidae indet. f Tryonia semituberculata. g Eupera/Musculium sp., connected valves. h-i Unidentified charophyte oogonia (in situ). J Undetermined fruit shell (carbonized). k-m Actinopterygian vertebrate remains. $\mathrm{k}$ Tooth of an unidentified serrasalmine characoid. $1-\mathrm{m}$ Pharyngeal teeth of unidentified actinopterygians. Scale bars equal $10 \mathrm{~mm}(\mathrm{a}-\mathrm{b}), 1 \mathrm{~mm}(\mathrm{c}-\mathrm{g}, \mathrm{k})$, and $0.5 \mathrm{~mm}(\mathrm{~h}-\mathrm{i}, \mathrm{l}-\mathrm{m})$
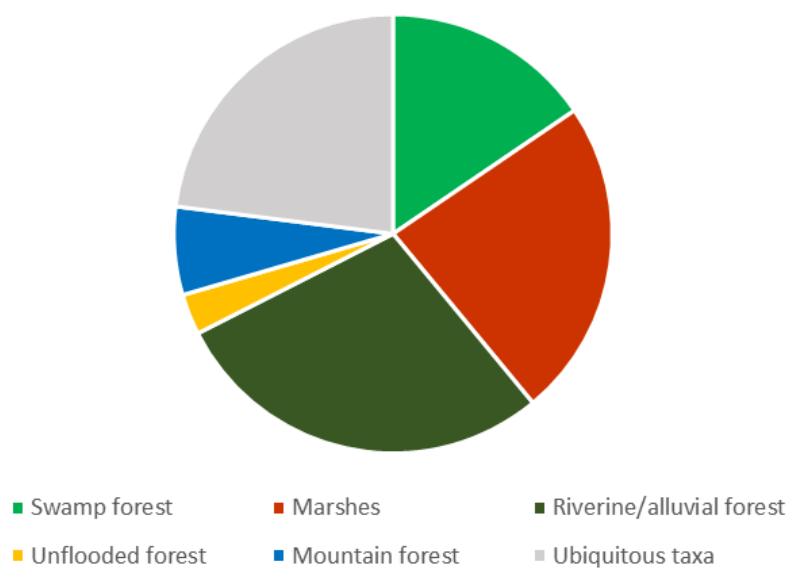

Fig. 7. Vegetation types found at TAR-27 from pollen and spore data. Taxa gathered in the different groups based on their ecological preferences are: Riverine/alluvial forest: Combretaceae/Melastomataceae, Alchornea, Malvaceae bombacoidea, Stigmaphyllon, Tetrapterys. Swamp forests: Mauritia, Grimsdalea magnaclavata, Apocynaceae. Marshes: Cyperaceae, Ceratopsis, Ludwigia, Pityrogramma, Poaceae. Unflooded forests: Byrsonima, Euphorbiaceae, Fabaceae Caesalpiniaceae, Cassia, Bauhinia, Faramea, Sapium, Proteaceae. Mountain forests: Ericaceae, Cyathea, Anthurium, Lycopodium foveolate. Ubiquitous taxa: Lycopodiaceae, 
Lycopodium sp., Selaginella sp., Asteraceae, Fabaceae, Flacourtiaceae, Marantaceae, Fabaceae Mimosoideae, Polygalaceae, Rubiaceae, Urticaceae/Moraceae, Verbenaceae.

\begin{tabular}{|c|c|c|c|}
\hline Locality & Coordinates & Stratigraphic position & Paleontological content \\
\hline TAR-27 & $\begin{array}{l}\mathrm{S} 7^{\circ} 32^{\prime} 7.45^{\prime \prime} \\
\mathrm{W} \\
76^{\circ} 40^{\prime} 32.24^{\prime \prime}\end{array}$ & $\begin{array}{l}\text { Ipururo Formation, middle Member, } \\
\text { top }\end{array}$ & $\begin{array}{l}\text { Spores and pollen grains, } \\
\text { Algae, } \\
\text { Charophyte oogonia, } \\
\text { Crab molts, } \\
\text { Mollusk shells, } \\
\text { Microvertebrates (fish teeth and bones) }\end{array}$ \\
\hline $\begin{array}{l}\text { TAR-51 } \\
(=\text { STRI 110057) }\end{array}$ & $\begin{array}{l}\text { S 732'3.34”' } \\
\text { W 76² } 41^{\prime} 4.74^{\prime \prime}\end{array}$ & $\begin{array}{l}\text { Ipururo Formation, middle Member, } \\
\text { mid part }\end{array}$ & Leaf impressions \\
\hline TAR-52 & $\begin{array}{l}\text { S 731'58.98', } \\
\text { W 764 } 41^{\prime} 9.96 "\end{array}$ & $\begin{array}{l}\text { Ipururo Formation, middle Member, } \\
\text { base }\end{array}$ & Leaf impressions \\
\hline
\end{tabular}

Table 1. Localities of interest in the Shumanza section, Huallaga Basin, San Martín Department, Peru: location, stratigraphic position, and paleontological content.

\begin{tabular}{|c|c|c|c|c|c|c|}
\hline & Family & Genus & Species & Photo & Ecology & Reference \\
\hline \multirow{5}{*}{ Lycophytes } & \multirow{3}{*}{ Lycopodiaceae } & Lycopodium & L. foveolate & Fig. 3a & \multirow{3}{*}{ Ubiquitous } & \multirow{3}{*}{ Marchant et al., 2002} \\
\hline & & Lycopodium & - & Fig. $3 b$ & & \\
\hline & & Undetermined & - & & & \\
\hline & \multirow{2}{*}{ Selaginellaceae } & Selaginella & - & Fig. $3 c$ & $\begin{array}{l}\text { Lowland to mountain } \\
\text { forests }\end{array}$ & $\begin{array}{l}\text { Marchant et al., 2002; } \\
\text { Jaramillo et al., 2010 }\end{array}$ \\
\hline & & Cingulatisporites & - & Fig. $4 b$ & $\begin{array}{l}\text { Extinct. Unknown } \\
\text { ecology }\end{array}$ & D’Apolito, 2016 \\
\hline \multirow{4}{*}{ Monilophytes } & Cyatheaceae & Cyathea & - & Fig. $3 d$ & $\begin{array}{l}\text { Tree fern of mountain } \\
\text { forests }\end{array}$ & $\begin{array}{l}\text { Marchant et al., 2002; } \\
\text { Jaramillo et al., } 2010\end{array}$ \\
\hline & Pteridaceae & Pityrogramma & - & Fig. 3e & $\begin{array}{l}\text { Ferns of moist and open } \\
\text { environments }\end{array}$ & Marchant et al., 2002 \\
\hline & Parkeriaceae & Ceratopteris & - & Fig. $3 f$ & Aquatic ferns of marshes & $\begin{array}{l}\text { Leite, 2009; Jaramillo } \\
\text { et al., } 2010\end{array}$ \\
\hline & Polypodiaceae & Undetermined & - & Fig. $3 \mathrm{~g}$ & & \\
\hline \multirow{6}{*}{$\begin{array}{l}\text { Angiosperm } \\
\text { monocots }\end{array}$} & Araceae & Anthurium & - & Fig. 3h & $\begin{array}{l}\text { Hemi-epiphytic of } \\
\text { tropical Andean and } \\
\text { Costa Rican altitude } \\
\text { forests }\end{array}$ & Marchant et al., 2002 \\
\hline & \multirow[b]{2}{*}{ Arecaceae } & Grimsdalea & G. magnaclavata & Fig. 3i & Extinct swampy palm & Hoorn, 1993 \\
\hline & & Mauritia & - & Fig. $3 \mathrm{j}$ & $\begin{array}{l}\text { Marsh forest, lowland } \\
\text { swamps }\end{array}$ & $\begin{array}{l}\text { Hoorn, 1993; } \\
\text { Marchant et al., } 2002\end{array}$ \\
\hline & Cyperaceae & Undetermined & - & Fig. $3 \mathrm{k}$ & $\begin{array}{l}\text { Lowland to high altitude. } \\
\text { Marshes }\end{array}$ & Marchant et al., 2002 \\
\hline & Marantaceae & Undetermined & - & Fig. 31 & & \\
\hline & Poaceae & Undetermined & - & & $\begin{array}{l}\text { Wide ecology, lowland to } \\
\text { high altitude }\end{array}$ & Marchant et al., 2002 \\
\hline \multirow{13}{*}{$\begin{array}{l}\text { Angiosperm } \\
\text { eudicots }\end{array}$} & Amaranthaceae & Undetermined & - & & $\begin{array}{l}\text { Herbs in open areas, } \\
\text { seasonally inundated, } \\
\text { salty soils }\end{array}$ & Marchant et al., 2002 \\
\hline & Apocynaceae & Undetermined & - & & $\begin{array}{l}\text { Trees, shrubs, lianas in } \\
\text { preferably moist forests }\end{array}$ & Marchant et al., 2002 \\
\hline & \multirow{3}{*}{ Asteraceae } & Undetermined & - & & $\begin{array}{l}\text { Wide ecology at family } \\
\text { level }\end{array}$ & $\begin{array}{l}\text { Marchant et al., 2002; } \\
\text { Barreto et al., 2015 }\end{array}$ \\
\hline & & Echitricolporites & E. spinosus & Fig. $3 \mathrm{~m}$ & Extinct Asteraceae & \\
\hline & & Fenestrites & F. longispinosus & Fig. $4 c$ & Extinct Asteraceae & \\
\hline & $\begin{array}{l}\text { Combretaceae/ } \\
\text { Melastomataceae }\end{array}$ & Undetermined & $\begin{array}{llll}0 & 0 \\
\end{array}$ & Fig. $3 n$ & $\begin{array}{l}\text { Riparian, lowland to } \\
\text { montane forest }\end{array}$ & $\begin{array}{l}\text { Marchant et al., 2002; } \\
\text { Jaramillo et al., } 2010\end{array}$ \\
\hline & Ericaceae & Undetermined & - & & $\begin{array}{l}\text { Wide ecology, mostly in } \\
\text { montane areas }\end{array}$ & Marchant et al., 2002 \\
\hline & \multirow{4}{*}{ Euphorbiaceae } & Alchornea & - & Fig. 30 & $\begin{array}{l}\text { Riverine forests, at low } \\
\text { to middle altitudes }\end{array}$ & $\begin{array}{l}\text { Marchant et al., 2002; } \\
\text { Jaramillo et al., 2010 }\end{array}$ \\
\hline & & Sapium & - & Fig. $3 p$ & $\begin{array}{l}\text { Trees and lianas, lowland } \\
\text { to mid altitude rainforest. } \\
\text { Treelet-scrub savanna } \\
\text { with Byrsonima }\end{array}$ & Marchant et al., 2002 \\
\hline & & Palaeosantalaceaepites & P. cingulatus & Fig. 4d & Extinct Euphorbiaceae & \\
\hline & & Undetermined & - & Fig. $3 q$ & $\begin{array}{l}\text { Trees, lianas, herbs } \\
\text { mainly lowland to lower } \\
\text { montane rainforest }\end{array}$ & $\begin{array}{l}\text { Marchant et al., 2002; } \\
\text { Jaramillo et al., } 2010\end{array}$ \\
\hline & Fabaceae & Undetermined & - & Fig. $3 r$ & Wide ecology & Barreto et al., 2015 \\
\hline & & Bauhinia & B. acuminata type & Fig. $3 \mathrm{~s}$ & Dry areas & \\
\hline
\end{tabular}




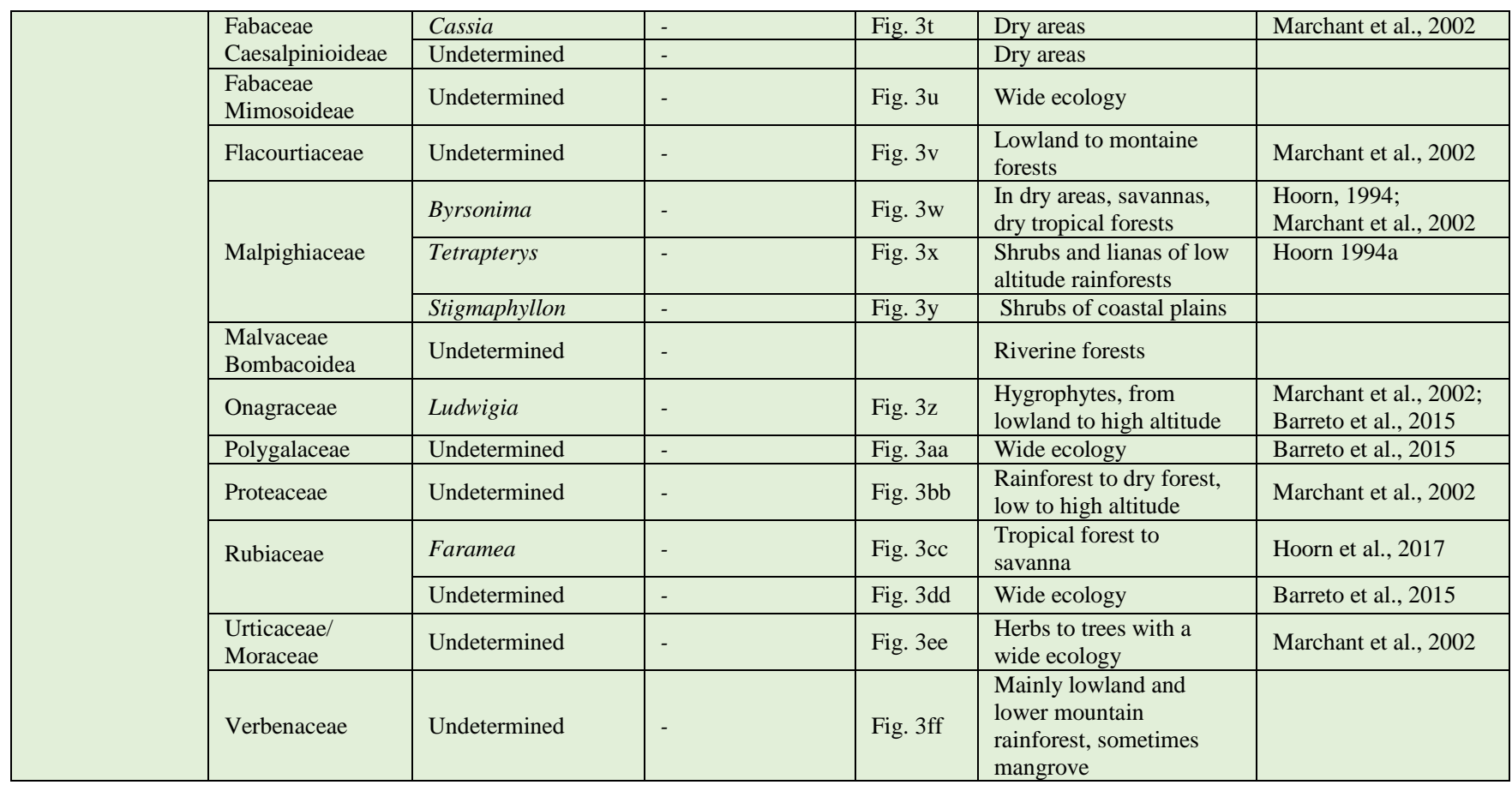

Table 2. Classification based on Cole et al. $(2018,2019)$ and ecology of identified Neogene plant taxa from the Shumanza section, Huallaga Basin, San Martín Department, Peru. 